Putnam (2000)

Coñán: KörösényiTóth-Török (2003)és Enyedi-Körösényi (2001)

A bizalom hálója kifejezést Utasi Ágnestốl kölcsönöztem. Utasi (2002)

A hécsi illetổségü Dunagốzhajózási Társaság a XIX század folyamán megszerezte a Pécs környékén lévố szénbányák tulajdon, illetve bérleti jogát, és jelentốs fejlesztéseket hajtott végre a régióban.

Annyira nem vált a város szerves részévé, hogy a Pécs térképen nem is szerepel, csak néhány, Pécs környékét ábrázoló térképen jelölik. A szomszédos Rücker -aknát pedig még kevesebb térkép „ismeri”.

Olyannyira elfelejtett terület, hogy még a legutóbbi népszámlálási adatokból sem tudtuk meg a pontos la kosságát, így a kutatás során végeztük a lakosságszám felmérését, ezért csak közelítő szám áll a rendelkezésünkre.

Bár ez a program nem a városvezetés érdeme, hanem egy maréknyi elhivatott emberé.

Körösényi-Tóth-Török (2003) és Enyedi-Körösényi (2001)

Csizmadia (2002)

10 Putnam (2000)

11 Tocqueville (1998)

12 Az anómia fogalmát Durkheim vezette be, amit késốbb Merton újraértelmezett. Több változáson átesett a fog en a fogalmat a durkheimi értelemben

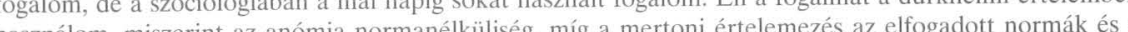
hasznáom, miszerint az anomiá normanelkúníség, míg a ménít.

valóság közti

13 Utasi (2002b)

15 Az ott töltött egy hét alatt eljutottunk gyakorlatilag minden lakásba, és mindenhol megkérdeztük, hogy Az ott töltött egy hét alatt eljutottunk gyakorlatilag minden laḱsäba, es minazért volt szükség, mert, mint hányan élnek az adott háztartásban, és a kapott adatokat osszesitettük. Erre

már említettem, nem állt rendelkezésünkre pontos adat a lakosságot illetốen.

6 Az eredeti tervünk szerint nem kérdeztünk volna 18 évesnél fiatalabbakat, de a helyzet úgy hozta az említett 3 esetben nem tudtuk megkerülni. Természetesen szülői engedéllyel kérdeztük ốket.

7 Erre azért volt szükség, mert az utolsó országgyülési választások 2002-ben voltak. Természetesen, aki fiatalabb 22 évesnél, az nem biztos, hogy nem szavazhatott az utolsó országgyúlési és önkormányzati választásokkor, de mivel a születési hónapot nem kérdeztük, ezért utólag nem állapítható ez meg, így a torzítå elkerülése végett volt szükség a szúrésre. A késôbbiekben, ahol egyenként vizsgálom az itemeket, a népszavazás esetében elég lett volna a 19 évnél fiatalabbakat szürni, de az összehasonlithatóság és az átláthatósàg érdekében nem változtattam a szűrési szabályon.

18 Körösényi-Tóth-Török (2003) és Enyedi-Körösényi (2001), www.valtor.valasztas.hu/valtort/jsp/index.jsp

9 Körösényi-Tóth-Török (2003) és Enyedi-Körösényi (2001), www valtor valasztas.hu/valtort/jsp/index jsp

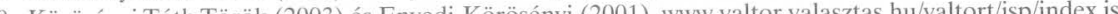

Körösénvi-Töth-Török (2003) es Enyedi-Körosenyi (2004), www valtor valasztas.hu/valtort/spindex.jsp

1 Utasi $(2002 \mathrm{~b}$

22 Utasi $(2002 b)$

\section{A társadalmi kirekesztődés társadalmi tőke szempontú megközelítése rurális-urbánus összehasonlításban}

\author{
A mikrotársadalmi szolidaritás és a közösségalkotás \\ lehetősége a leszakadó térségekben, Pécs-István-aknán \\ és Magyarteleken
}

Aársadalmi kirekesztődés a társadalomtudományokban az 1990-es évektól kiAalakuló, majd az ezredfordulótól megerôsödő kutatási irányzat. A társadalmi kirekesztôdés szociológiai problémája a hagyományos szegénységkutatások helyett komplexebb megközelítésmódra ad lehetôséget a leszakadó térségek, azaz a társadalmi integráció hiány térbeli koncentrációjának empirikus megragadásában. A leszakadó térségek, gettók kialakulásának vizsgálatakor e megközelítésmód szerint olyan dimenziókat kell figyelembe venni, mint a jövedelem, az életkörülmények, az életmód, a munkaerố-piaci pozíció, a tudás megszerzése, a térben koncentrálódó társadalmi hátrányok, illetve a társadalmi tốke. A társadalmi tốke, az emberi kapcsolatok szerepe jelenthetné a legfontosabb kapaszkodót a teljes dezintegrációba süllyedés ellen, ám ezek múködése még a szúk családi, baráti körre koncentrálódó kapcsolatok esetében sem magától értetốdố tény. Ezen kapcsolatok köre utolsó mentsvárként lenne hivatott biztosítani a mikrotársadalmi integrációt és megóvni, megtartani az egyént az emberi közösségekben.

E dolgozat fejtegetéseinek középpontjában egy pécsi szegregált városrész, Istvánakna, és egy ormánsági aprófalu, Magyartelek többségében hátrányos illetve halmozottan hátrányos helyzetû́ népességének társadalmi integráltsága, fóként a helyi mikrotársadalomba való beágyazottsága áll. E tekintetben a vizsgálat megpróbál számot adni többek között a lakóterületen élók egymás közötti transzfereiról, a személyes interakciók gyakoriságáról, az egymás iránti altruista, önzetlen magatartás viszonyairól, a közösségi tevékenységek részvételi hajlandóságáról, vagyis összefoglalva a mikrotársadalmi szolidaritás változóiról. A gondolkodásmód kiindulópontja a szolidaritást, mint a társadalmi integráció egyik lehetséges eszközét és/vagy alapját tételezố belátás.

A mikrotársadalmi beágyazottság jellemzőinek mintegy indikátoraként próbálom felhasználni a szolidaritási, önzetlenségi, kapcsolatorientáltságbeli attitúdváltozókra 
építô, közösségalkotásra irányuló hajlandóságot méró indexált mérószámot, nevez zük közösségalkotási potenciálnak. Azt gondolom, hogy ez a két vizsgálat ha nem is teljességében, de megfelelő mértékben képes számot adni és irányt mutatni az István-aknai és a magyarteleki emberek, mint társadalmi- és térbeli kirekesztettségben élók társadalmi beágyazottságának arról a szintjéról, melyet a közvetlen hely mikrotársadalmi környezet képes csupán biztosítani az egyén számára. Az elemzések a PTE BTK szociológia tanszékén 2005 és 2006 tavaszán lezajlott terepgyakorlatok során felvett adatokra épülnek. Ezek az adatok bár egy társadalmi tőke kutatásból származnak, azonban mivel István-aknáról ezt megelőzően semmiféle szociológiai, statisztikai adtafelvétel nem készült a népszámlálások kivételével ${ }^{1}$, e városrész esetében alapadatoknak számítanak.

\section{A mikrotársadalmi szolidaritás elméleti alapjai}

szociológiában ismert szolidaritással foglalkozó elméletek sorát, melyek a téAmánk szempontjából relevánsan körvonalazzák a vizsgálat elméleti alapjait, mind itt nem vehetjük számba. Csupán a teljesség igénye nélkül néhány fontos támpont vázolását ejtjük meg, melyek közül kifejezetten az utolsó szolgáltat majd mintát számunkra az adatok értelmezéséhez. A szolidaritással elsóként Durkheim (Durkheim, 2001) munkáiban találkozunk, aki a társadalmi munkamegosztást létrehozó, preindusztriális és iparosodott társadalmak szolidaritástípusait választja külön mechanikus szolidaritásra, és organikus szolidaritásra. A számunkra fontosabb mechanikus szolidaritás a munkamegosztást nem intézményes személytelenül szervezet gyakorlat szerint, hanem a kisközösségekben, a családi, rokoni, baráti kapcsolatok hasonlóság alapján létrejövő együttműködéseire építi. A mechanikus szolidaritással szervezett közösségek fennmaradásának feltétele, az egymás szükségleteit messzemenôen figyelembe vevố cselekvés és gondolkodás.

A szolidaritáshoz kapcsolódó számos elmélet közül kiemelhetố még Tönnies (Tönnies, 1983) közösségre és társadalomra bontott társadalomszerkezete, Weber társadalmi kapcsolatokból levezetett szolidaritás-elmélete (Weber, 1987), vagy akár a társadalmi tókével foglalkozó James Coleman is, aki szerint a társadalmi tőke „értékesítésével”, a kapcsolathálózatokon belüli cserékkel alakul ki szolidaritás (Coleman, 1998).

Ez a dolgozat azonban közvetlenül Utasi Ágnes 2000-ben, országos reprezentatív mintán végzett bizalommal és mikrotársadalmi szolidaritással kapcsolatos vizsgálatához, illetve az abból készült összefoglaló munkához kapcsolódik (Utasi, 2002). Ez annál is inkább szükségszerú, mivel a jelen dolgozat alapját képző kutatások már az adatfelvételeket megelőzően, a módszer megválasztásakor és kidolgozásakor erre a munkára alapozódtak többek között. Ennek megfelelốn elfogadottnak gondolom e kutatás elméleti és metodológiai megfontolásait, csakúgy, mint a nyert adatok érvényességét és megbízhatóságát. Igaz azonban, hogy a mi István-aknai és magyarteleki kutatásunk legalább két jelentôs sajátosságában különbözik a szóban forgó vizsgálattól, ugyanis kifejezetten a társadalmi tốke problematikájára koncentrált, és egy-egy jól körülhatárolható, kis létszámú, homogén, zömében hátrányos vagy halmozottan hátrányos helyzetú, a társadalmi struktúra legalsó rétegeiben helyet foglaló társadalmi csoport egészét vizsgálta. Ennek ellenére, mivel a módszer a legtöbb ponton megegyezik az Utasi Ágnes által végzett kutatásban használtakkal, sem az elméleti alapvetések átvétele, sem az adatok összevetése nem okozhat problémát.

A hivatkozott kutatás a mikrotársadalmi szolidaritás különbözô dimenziói mentén (melyeket mi is vizsgálat tárgyává tettünk) a következőképpen írja le a magyar társadalmat. A bizalmas baráti kapcsolatok száma jelentôs eltérést mutat az iskolai végzettség szerint, a nemi megoszlás függvényében, az eltérổ korcsoportok esetében, a munkaerốpiacon elfoglalt pozíció, és általában a társadalmi struktúra hierarchiájában elfoglalt hely tekintetében. Ezek mentén minél elönyösebb pozíciókat birtokol valaki, annál több baráti kapcsolat kialakítására, és birtoklására van módja. Ezek mellet magasabb számban van baráti kapcsolatuk a férfiaknak, s a kor elốre haladtával csökken a bizalmas baráti kapcsolatok száma a fiatalabb generációktól az idôsebbek felé haladva. Az egyenlôtlenségek kihatnak az egyén önértékelésére, beépülnek a tudatba, és azon keresztül visszahatnak az életfeltételekre, és a barátválasztásra is. A társadalmi hátrányok okként, a társadalmi-tôke fogyás okozatként tételezôdik. Minél több hátrányt kell elszenvednie valakinek, annál kevesebb bizalmas, segítô kapcsolata van. A bizalmas kapcsolatok hiánya megállapításuk szerint izolációt eredményez, visszaha az életminôségre, $\mathrm{s}$ gyakran vált ki boldogtalanságérzést. Az önzetlen segítségnyújtás, és a kölcsönös reciprocitást, anyagi ellenszolgáltatást nem feltételezô altruista magatartás a fiatalokra jellemzóbb mint az idôsekre, a férfiakra inkább mint a nôkre, az iskolai végzettségben elért magasabb státuszúakra inkább, mint a 8 osztállyal, vagy az alatti iskolázottsággal rendelkezókre. A kedvezóbb életfeltételekkel rendelkezők forráserôsebbek mint a hátrányokkal küzdők, s így a magasabb státuszúak többször nyújtanak önzetlenül segítséget. Az alacsonyabb szinten elhelyezkedố rétegek segítségnyújtását ezen kívül inkább az úgynevezett elnyújtott reciprocitás ${ }^{2}$ jellemzi, vagyis a közvetlenül nem, de a jövő folyamán valamikor elvárhatónak vélt viszonzásra alapozott altruizmus. Kapcsolatot mutattak ki ezen kívül a segítségnyújtás mértéke és a családi rokoni kapcsolatok intenzitása között is.

\section{Megkötő társadalmi tôke}

társadalmi tóke fogalma tulajdonképpen a társadalmi integráció hagyományos Aszociológiai problémájának újrafogalmazását jelenti. Sok kritika érte a társadalmi tốke elméletét, mivel rendkívül szélesre tárja a vizsgálódás körét és így zavaros maradt, hogy mikor nagyobb vagy kisebb a társadalmi tóke koncentrációja egy adott család, város, vagy egy egész társadalom vonatkozásában. Az elmúlt években részben e kritikákra való reakcióként is megszületett egy osztályozás, mely elkülöníti a társadalmi tóke három formáját.

„megkötố”: olyan intenzív kapcsolatok tartoznak ide, melyek ráerôsítenek az eleve együvé tartozókat magukba foglaló csoportok határaira és ezzel kívül hagynak, „kirekesztenek" minden nem oda tartozót. Ilyenek például a család, a közeli barátok vagy szomszédok, falubeliek. 
„osszekötô": olyan lazább kapcsolatok alkotják, amelyek összekötik a különbözó

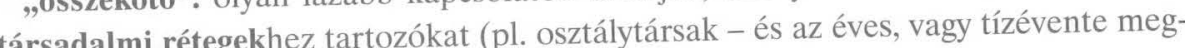
rendezésre kerülő osztálytalálkozók). Már a 19. század elején felfigyelt az arisztokraszármazású francia tudós utazó, Alexis de Tocqueville arra, hogy az 1830-as évek Amerikájában milyen magas fokon múvelték a társulás múvészetét: a legkülönfélébb hátterű amerikaiak szövetkeztek egymással, „társulásokat” hoztak létre, hogy céljaikat megvalósítsák. Tocqueville és mai társadalomtudós követói szerint ez a spontán társas készség a kulcsa az erôs civil társadalomnak.

„összekapcsoló”: olyan kapcsolatok, amelyek a befolyással bíró pozíciókban lévốk”öz kötnek minket, pl. a civil szervezetek és a kormányzat közötti partnerség, de ilyenek a korrupciós kapcsolatok is (,jó kapcsolatok").

A társadalmi tốke három típusa különböző koncentrációban és egymáshoz viszonyít-

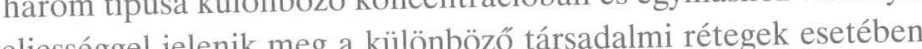
va különbözó erốteljességgel jelenik meg a külonbozo társada A kutatási eredmények azt a feltételezést támasztják alá, hogy a térben is koncentrálódó hátrányokkal jellemezhető olyan térségekben élők körében, mint a nagyvárosi ettók, vagy az elszegényedett aprófalvak, rendkívül nagy jelentốsége van a mindennapi boldogulás szempontjából a megkötő társadalmi tőkének, míg az elóbbre jutás egyik legkomolyabb gátját az összekötố, valamint az összekapcsoló társadalmi tôke gyengesége okozza. Utóbbiak biztosíthatnák a munkahelyek megszerzéséhez vagy a vállalkozói tevékenységhez szükséges feltételek biztosításával kapcsolatos erőforrásokhoz és információhoz való hozzájutást." A következőkben vizsgált két deprivált település közötti hasonloságok, a társadámi kireksztötés társadalmi tőke vizsgálatát méleti keretein belül a kapcsolatok esetében a megötó társadalmi tóke vizsgálatát teszik szükségessé elsốsorban, a területek demográfiai mutatói és a mikrotársadalmi szolidaritásban betöltött kulcsszerepe miatt.

Ezek alapján a következő tézisekre alapozom okfejtésemet.

A civilizációsan fejlett társadalmakban az ipari forradalom óta terjedô individualizációs stratégiák dezintegrációs hatásai kikezdték a Durkheim által elgondolt mechanikus os strategás, fözösségi társadalmak gemeinschaft szervezố elveit, szolidaritás, vagy a Tönnies féle közösségi tarsadarín erôs gyengülése figyelhetố meg. aminek következményeként a tarsadal króbban sokkal nagyobb körre kiterjedổ kap Az egyének bizalmi attitúdjei, melyek korábban sokkal nagyobb köre kiterjedó kap csolati hálókat voltak képesek kialakítani, az individualizáció erodáó hatasára mén a szúk családi, baráti, rokoni körre korlátozódtak. A szolidaritás, az önzetlenség, a bizalom csökkenése, a társadalmi tôke-fogyás fôként a társadalom alsó rétegeiben élô szegényebb népesség előrejutási lehetőségeit korlátozzák nagymértékben. Ezekbó kifolyólag a hátrányosabb helyzetû, társadalmi kirekesztettségben élők, és mobilitás stratégiáikban korlátozottak integrációját a társadalomba az intézményi integrációt célzó kormányzati intézkedések már nem képesek hatékonyan ellátni (ha egyáltalán valaha is képesek voltak), vagyis felértékelődik a mikrotársadalmak integrációs jelentôsége. A mikrotársadalmon belüli szolidaritás kiterjedtsége ennél fogva eszköze, és egyben magyarázó változója is a jelzett társadalmi csoportok beágyazottságának.
A kérdés, melyet megpróbálok megválaszolni ezek alapján tehát az, hogy a vizsgált rurális illetve urbánus városrészben/aprófaluban élớk csoportja, melyeket a lakóterületek kis népességszámából és összetétele szerinti homogenitásából adódóan nyugodtan tekinthetünk mikrotársadalomnak, milyen mértékben ágyazódik a helyi közösségbe és milyen minőségú a lakók egymás közti szolidaritása, illetve megkötố társadalmi tôkéje.

\section{A vizsgálat módszerei}

z adatfelvétel kérdőíves módszerrel végzett teljes körủ lekérdezés volt. A kérAdốív egyes item-jei egy angol társadalmi tóke felvétel bevett kérdéseiból a magyarországi viszonylatokat, és a kutatási terepünk sajátosságait figyelembe véve releváns változókat használta fel, melyek kiegészültek az Utasi Ágnes féle kutatás egyes változóival, illetve néhány specifikusan a terepre vonatkozó kérdéssel. István-akna esetében egyéni kérdőíveket használtunk, míg Magyarteleken a háztartások egy-egy tagja szolgáltatott információt a többi tagról is.

Az elemzésben a mikrotársadalmi beágyazottság változóit leíró statisztikai adatokka magyarázom és a következók szerint csoportosítom: 1. Lakóhelyi beágyazottság, 2. Kap csolatok, 3. Transzferek. A közösségalkotási potenciál esetében a fontosnak ítélet közösségalkotási hajlandóságot magyarázó változókból kialakított indexet használom fel. A mikrotársadalmi beágyazottságnál figyelembe vett változók a következők: a lakóhelyen élés ideje, az lakóhellyel való elégedettség, a közösség szolidaritásának egyéni megítélése, a bizalom kérdése, az egymás között áramoltatott transzferek, a rokonok, barátok számának nagysága, és a szomszédsági viszonyok/kapcsolathálók kiterjedtsége.

\section{István-akna}

Tstván-akna Pécs észak-keleti peremterületén elhelyezkedô, a város összefüggő Iszerkezeti egységétôl markánsan elkülönülô, ám közigazgatásilag mégis a városhoz tartozó városrész. Létrejöttét a 19. század végén, a pécsi szénbányák Pécs környéki ipari területeinek kialakításával összefüggésben kell megérteni (Huszár, 2003). A 19-20. század fordulóján kibontakozó, fénykorát az államszocialista ipari termelés alatt elérố, majd a 80'-as évek folyamán hanyatlásnak induló mecseki fekete kốszén bányászat fontos szerepet játszott abban, hogy a Pécstôl különböző távolságban lévố kitermelések helyszínei közvetlen környezetében lakóövezetek alakultak ki. Az így létrejött „mikrotelepülések” késóbb Pécs közigazgatási részeivé váltak, habár a várostól való térbeli elkülönülésük esetenként meglehetốsen nagy volt. Ilyen részei ma Pécsnek Pécs-Vasas, Pécs-Somogy, Pécs-Hird, vagy István-akna. Ez a térbeli különállás, térbeli kirekesztettség majd egy évszázadon át problémamentes volt, hiszen az itt élő emberek állandó munkalehetóséggel rendelkeztek, sốt a szocialista rendszer ipari termelést preferáló gazdasági orientációja a bányászat iparágában dolgozókat magasan értékelte. Ennek köszönhetốen 1923-tól, István-akna felszentelésétól és a bánya körüli kolónia kialakulásától kezdve az itt élôk társadalmi presztízse kitüntetett szerepet köl- 
csönzött nekik. Ez nem csupán jövedelmükben mutatkozott meg, hanem a társadalmi integráció „intézményi szintjén”, vagyis a közintézményekkel, közösségi helyszínekkel való ellátottság magas fokában is. István-aknán a magyarországi rendszerváltozást megelőzően múködött iskola, óvoda, kultúrház, mozi, postahivatal, bolt ${ }^{3}$. A bányászok számára kialakított lakóépületek körében megtalálhatóak a magas szakmai-, s ného esztétikai igényességgel kialakított bányatiszti házak, és a kevésbé igényes de még kiemelkedố minóségú (a korszaknak megfelelően) bányászházak, melyek a terület nagyobb hányadát fedik le, illetve a bányászok számára átmeneti szállást jelentô két szintes munkásszállók. Figyelemre méltó, hogy hiányoznak a hagyományos félkomfortos vagy komfortnélküli rendkívül kicsi és minôségileg is problémás bányászházak, ami arra utal, hogy az István-aknai állandó lakók fóként a bányászat menedzsmentjét képezték (bányatisztek, termelésirányítók, irodai dolgozók, stb.). Azonban nyilvánvalóan az épületek többségét a bánya ipari létesítményei teszik ki: volt bányamentô központ, üzemcsarnokok, gépházak, irodaházak, aknatorony ${ }^{4}$.

A változást a mecseki szénkitermelés '80-as évektól kezdődố fokozatos leépítése, majd az 1990-es évek eleji bányabezárások sora hozta. Az addig magas társadalmi presztízzsel rendelkező népesség elvesztve megélhetési forrását többnyire elvándorolt István-aknáról, s az ottmaradtak számára megindult a lefelé csúszás a társadalmi lejtőn. Elindult egy filtrációs folyamat is ezzel párhozamosan. Mivel az épületek többsége a pécsi önkormányzat tulajdonába kerülve önkormányzati szociális bérlakásként funkcionált és funkcionál még ma is tovább, a városrészbe költözők szinte kivétel nélkül hátrányos-, vagy halmozottan hátrányos helyzetû́ emberek. A közintézmények eltûntek, a munkalehetôségek megszúntek, az életfeltételek minőségi romlása, és a környezeti adottságok öngerjesztő folyamatként alakították ki István-akna mai szegregált, térbelileg és társadalmilag is kirekesztett, leszakadó városrészi tulajdonságait.

A városrész térbeli szerkezetét meghatározó egyetlen utca két oldalán helyezkednek el a bányász illetve bányatiszti kertes családi házak. Amint azt már említettük István-akna tipikus példája a bánya ipari területei közvetlen szomszédságában kialakuló lakónegyedeknek, ebból kifolyólag a bánya valamikori épületei a lakóházak között is megtalálhatóak, mélyen benyúlnak a családi házak közé. István-akna „végét” az egykor munkásszállókként funkcionáló kétszintes téglaépületek (jelenlegi önkormányzati szociális bérlakások) zárják. Az infrastrukturális ellátottság hiányos, nincs gáz, a szennyvízelvezetés nem megoldott, a villany-, víz-, szennyvízvezetékek többsége közel 60 éve nem voltak felújítva, ahogy az épületek sem.

\section{Magyartelek}

z ormánsági aprófalvak példáját szemlélhetjük Magyartelek esetében. A SzentAlőrinc és Sellye között félúton, Gilvánfa szomszédságában elhelyezkedô falu jóval régebbi múltra tekint vissza mint István-akna. A vidéki falvak többségének mintájára az itt élők megélhetését mindig is a mezőgazdaság biztosította, ámbár most a pécsi munkalehetóségek vonzása és a mezőgazdaság folyamatos leépítése egyre kevésbé ad lehetôséget a mezốgazdaság nyújtotta foglalkozásokból való megélhetésre.
Mindemellett Magyarteleken még most is jelentốs az agrárnépesség aránya, akike fóként a helyi termelőszövetkezetben foglalkoztatnak. Magyartelek legjelentősebb különbsége István-aknával szemben az, hogy a közösségi tevékenységek számára adott lehetôségek jobbak, sốt ezek kihasználtsága is. Nem elhanyagolható szempon egy közösség életében, hogy annak van-e egy felelősséget érzô elhivatott és tevékeny vezetóje (legyen akármilyen temperamentuma is) mint Magyarteleken vagy sem. István-akna esetében ez komolyabb nehézségekbe ütközik. Mint városrész ebben az esetben ez a személy a városrész önkormányzati képviselôje lenne, ám mivel Pécs e részének képviselójéhez nem csupán István-akna tartozik, hanem több kisebb terület is, és ebből adódóan a hozzá tartozó emberek száma is jóval nagyobb, az István-aknára fordított figyelem is kevesebb. Hogy ennek oka valóban e problémákból, vagy más okokból adódik az külön kérdés.

Magyartelek rendelkezik közösségi házzal és azzal a képességgel, hogy ezt a lehetőséget tartalommal töltse meg. Különbözô rendezvények, bálok helyszínéül szolgál, és mint megtudtuk lelkigyakorlatos-, terepgyakorlatos csoportok elhelyezésére is alkalmas lesz hamarosan. Bár templom nincs, a faluban lakók felekezetek szerinti megoszlásától függően használják a közösségi házat vagy a polgármesteri hivatalt Szentmisék vagy Istentiszteletek bemutatására. Ezek mellet a közintézmények köre a boltban és a már említett polgármesteri hivatalban merül ki.

Magyartelek térbeli sajátosságai annyiban hasonlítanak István-aknához, hogy mind össze két rövid utcából áll, és hogy más lakott területtól jelentôsen elkülönül, azonban ez egy falu esetében magától értetôdó.

\section{A kemény változók}

stván-akna és Magyartelek mai társadalmi képe a kemény változók alapján a köIvetkezóképpen alakul. A nemi megoszlás szinte egyforma mindkét területen, a megkérdezettek több mint fele nô. István-aknán a népesség közel 70\%-a rendelkezik legfeljebb 8 általános iskolai végzettséggel, vagy még azzal sem, középfokú (fóként szakmunkás illetve szakközép iskolai) végzettsége a válaszadók 1/3-nak van, és felsófokú végzettsége a válaszadók mindössze 3,5\%-nak. Magyarteleken ezzel szemben magasabb a 8 általánost el nem végzettek aránya, viszont összességében a maximum 8 osztállyal rendelkezóké szinte megegyezik István-akna adataival.

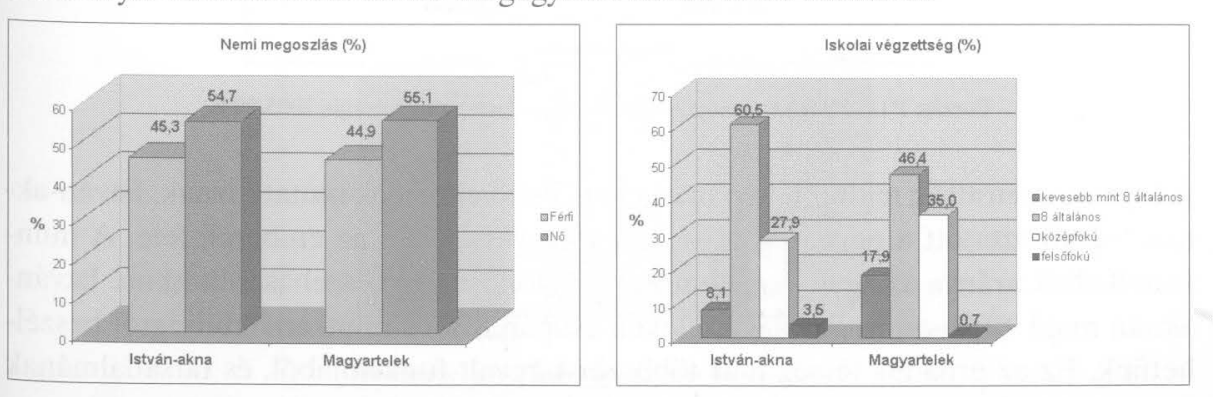

Forrás: PTE BTK szociológia tanszék, társadalmi tôke kutatás 2005/2006 
Élettársi vagy házastársi kapcsolatban áll a megkérdezettek közel 70\%-a mindkét területen. A 40 év felettiek aránya közel egyforma mindkét esetben, bár a 60 éven felüliek az ormánsági aprófaluban háromszor annyian vannak, mint István-aknán. Ez a magyar falvak elöregedó társadalmának problémáival magyarázható, bár a 18 éven aluliak aránya sem lebecsülendô. Ez István-aknával összevetve az egyik legfontosabb különbség, hiszen bár ott a 18 éven aluliakról nem vettünk fel adatokat, mégis tudjuk, hogy a 300 fốs népességbőll kb. 200 a 18 éven aluli fiatalabb generációhoz tartozik.
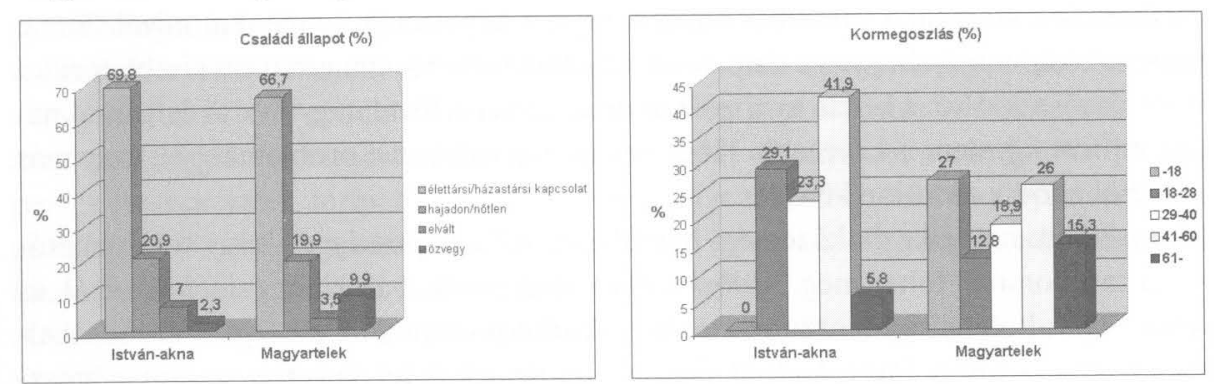

Forrás: PTE BTK szociológia tanszék, társadalmi tóke kutatás 2005/2006

Roma etnikumú a megkérdezettek több mint 2/3-a István-aknán, ellenben Magyarteleken ez az arány mindössze 1/3-ad körüli. Ez azzal magyarázható, hogy mivel István-akna lakóépületei többségében önkormányzati tulajdonú szociális bérlakásként funkcionálnak, a Pécsett történố telepfelszámolások következtében a hátrányos helyzetú emberek (akik között mint ismert a roma népesség felülreprezentált) egyik célállomása ez a városrész.

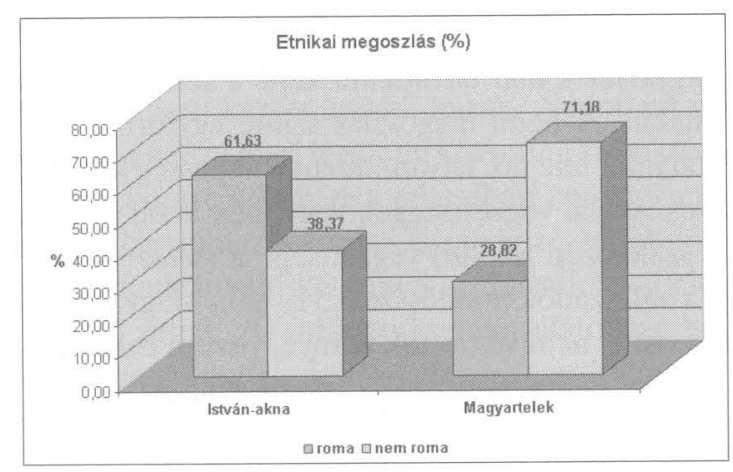

Forrás: PTE BTK szociológia tanszék, társadalmi tôke kutatás 2005/2006

A foglalkoztatottság tekintetében már jelentősebb eltérések mutatkoznak. István-aknán foglalkoztatott a népesség 1/3-a, míg Magyarteleken az emberek fele. A munkanélküliek aránya az egyik legjelentốsebb különbség az összehasonlításban. Istvánaknán majd $40 \%$-os, míg Magyarteleken csupán 8\%-os munkanélküliségról beszélhetünk. Ez az urbánus térség már többször tárgyalt funkciójából, és társadalmának összetételéból adódik. Kiemelkedô különbség van még a nyugdíjasok, és a szakmun- kások között, melyet résszint a falvak elöregedố társadalma, résszint a mezógazdasági munka által biztosított megélhetés magyaráz. Érdemes még megemlíteni azt is, hogy Magyarteleken a szak- és betanított munkások bizonyos hányada a pécsi Elqotec cégnél dolgozik, a beszállítást pedig a cég külön buszjáratokkal biztosítja. A vidéki munkalehetôségek korlátozottsága miatt ez azon ritka esetek egyik példája, amikor a gazdasági szereplốk a negatív társadalmi folyamatok elốmozdítása helyett azokkal szemben tesznek intézkedéseket, bár az adatfelvétel során kialakult beszélgetések alapján a helyi fiatalok mobilitási stratégiái Pécs irányába mutatnak.

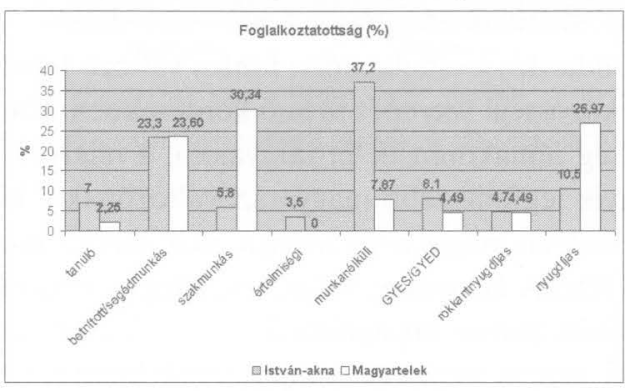

Forrás: PTE BTK szociológia tanszék, társadalmi tôke kutatás 2005/2006

\section{Mikrotársadalmi szolidaritás}

\section{Lakóhelyi integráltság}

bból a feltételezésbő̉l kiindulva, hogy minél hosszabb ideje él valaki egy adott A településen, egy adott közösségben annál inkább érzi azt sajátjának, és annál inkább hajlandó önzetlenséget és szolidaritást vállalni másokkal, lehet releváns az a kérdés a témát illetôen, hogy mióta él valaki a szóban forgó közösségek egyikében. A városrész népességének jelentốs többsége (70\%) több mint 11 éve él ott, azaz a rendszerváltás környékén, vagy azt megelôző́en költözött oda. Ez azt is jelzi számunkra, hogy egy részük, akik több mint 20 éve élnek itt valószínúleg a bányászatban dolgoztak, vagy valamely rokonuk az volt. Ôk minden bizonnyal emlékeznek még Istvánakna „fénykorára” és annak tökéletes ellentétét erős traumaként érzékelik.

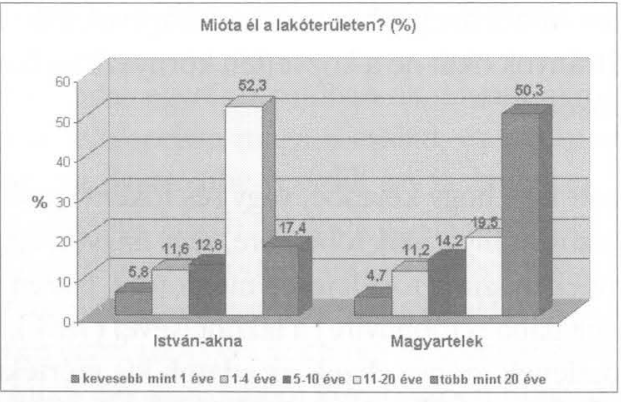

Forrás: PTE BTK szociológia tanszék, társadalmi tốke kutatás 2005/2006 
Magyarteleken ez teljesen hasonló képet mutat azzal a különbséggel, hogy míg István-aknán a 11-20 éve, Magyarteleken a több mint 20 éve élók csoportja emelkedik ki messze a többi kategória fölött. Azonban fontosabb az, hogy akár már öt eltöltött év is bizonyos mértékủ meggyökerezettséget, beágyazottságot eredményezhet kialakult kapcsolatokkal. Ez annak ellenére is így van, ha a környezeti feltételek hiányosságai, és az életminőség alacsony színvonala mintegy szimbiózist alkotva alakítja ki az egyénben saját lakóhelyének „rosszként” való megítélését, és fogalmazza meg a vágyat az elköltözés iránt. Az István-aknai népesség lényegi többsége több mint 5, akár több mint 10 éve él itt, akárcsak Magyarteleken.

A lakókörnyezeti szolidaritás kiemelkedôen fontos változó lehet a bizalmi attitűd és a mikrotársadalmak közösségi szerepét firtató kérdésekben. Ennek megfelelóen bár a lakóhelyi integráltság témakörén belül tárgyalom, a mikrotársadalmi szolidaritás szempontjából az egyik legfontosabb magyarázóváltozónak tekintem ezt a kérdést. István-aknán kiemelkedốn magas azok aránya, akik szerint inkább mindenki maga boldogul és kevésbé létezik közösségi tudat, míg Magyarteleken ugyanez a csoport lényegesen kisebb, bár itt sem elhanyagolható.

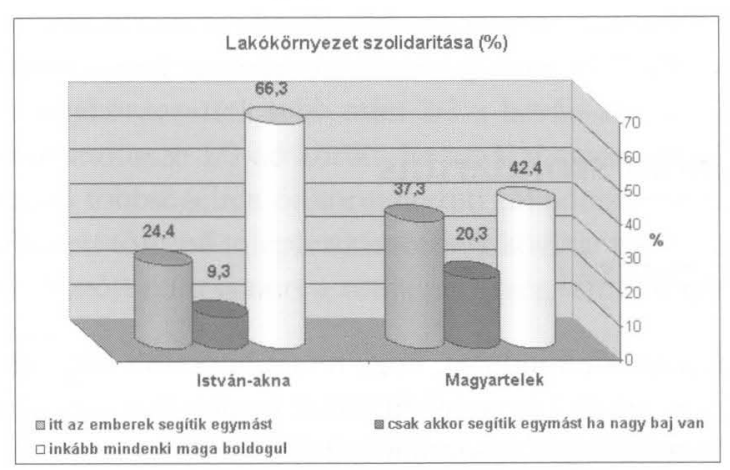

Ugyanitt 2/3 azok aránya, akik megítélése szerint valamilyen mértékû́ szolidaritás létezik a faluban, ebbő́l következően a bizalmas kapcsolatok számánál is magasabb arányra következtethetünk.

Míg eddig a szolidaritás létét vizsgáló változókat elemeztük, most annak valamifajta mértékére is következtetnünk kell. A lakóhellyel, mint fizikai és társadalmi környezettel való elégedettség már adhat arról számot, hogy a mikrotársadalmi szolidaritás mértékủ milyen, hiszen minél nagyobb a bizalmas kapcsolatok száma, annál erốsebb a késztetés, hogy a hátrányok okát ne a közvetlen környezetre hárítsa az ember, problémáit ne vetítse ki másokra.

A lakók 67\%-a válaszolt úgy, hogy kevésbé, vagy (és főként) egyáltalán nem elégedett István-aknával, és $1 / 3$ azok aránya, akik többnyire, vagy nagyon elégedettek lakóhelyükkel. Ugyanez Magyarteleken szinte tökéletesen megfordul, hiszen az emberek többsége nagyon elégedett (de legalább is többnyire) a lakóhelyével (78\%), és elenyészỏ a kevésbé elégedettek/elégedetlenek aránya. Ezek az adatok kis mértékủ beágyazottságra és szolidaritásra utalnak István-aknán, és jól múködő közösségre Magyarteleken.

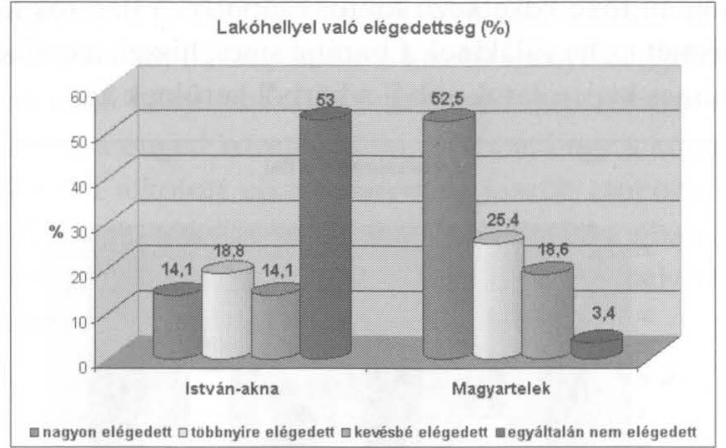

Forrás: PTE BTK szociológia tanszék, társadalmi tôke kutatás 2005/2006

\section{Kapcsolatok}

rokoni, baráti, szomszédi kapcsolatok körei, azaz a megkötố társadalmi tôke a - mikrotársadalmi szolidaritás vizsgálatának alapját képzik. Ezek közül is kiemelt szerepe van a közvetlen személyes interakciók gyakoriságának, mintegy biztosítva az egyén számára társadalmiasultságának tapasztalását. Ezért kifejezetten fontos szerepet tölthetnek be ezek a kapcsolati hálózatok a kirekesztettség állapotában, így István- aknán és Magyarteleken. Az urbánus területen a válaszadók közel felének (46\%) 1 rokona sem él.

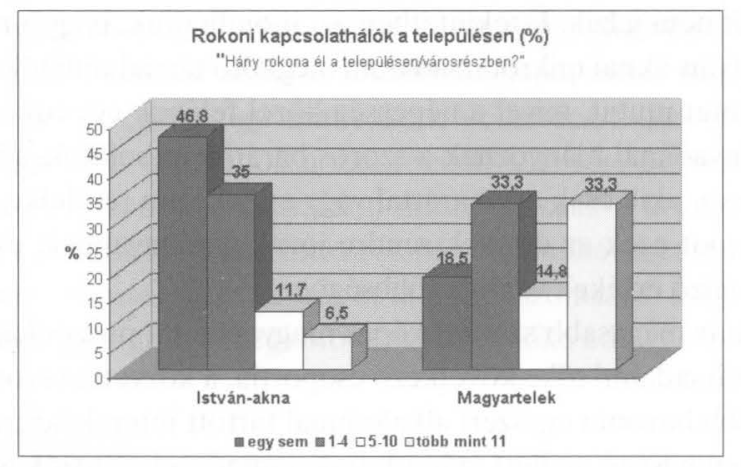

Forrás: PTE BTK szociológia tanszék, társadalmi tôke kutatás 2005/2006

Ez az aggasztónak látszó adat egyrészt valóban az, hiszen akire minden esetben támaszkodhat az ember az elsősorban maga a család, és István-aknán senkije sincs a lakók felének. Másrészt ha figyelembe vesszük azt is, hogy egy városrész esetében a város más területein is élhetnek közeli rokonok ez valamelyest javíthat ezen emberek megkötő társadalmi tốkéjének mutatóin. E terület térbeli elszigeteltsége ugyanakkor a nem túl könnyú megközelíthetôség miatt a rokonokkal tartott személyes kapcsolatok ellen hat. Magyarteleken ezzel szemben az emberek közel felének több mint 5 rokorna él, és csupán 1/5-nek nincs egy sem. Ebből következően Magyartelek megkötố társadalmi tốkéje jóval erôsebb, így a mikrotársadalmi szolidaritás szintjét is erősíti.

$2007-$ ôsz 
A megkötô társadalmi tóke következő fontos csoportja a barátok köre. A legkedvezôtlenebb válasz ismét az ha valakinek 1 barátja sincs, hiszen a család után következô legfontosabb bizalmas kapcsolatok ebból a körból kerülnek ki.

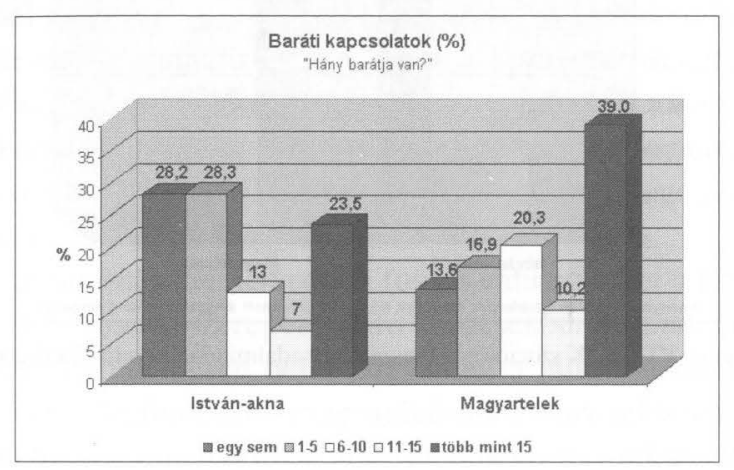

Forrás: PTE BTK szociológia tanszék, társadalmi tôke kutatás 2005/2006

A már elfogadhatónak vélt baráti kör véleményem szerint 6 fốtôl kezdôdik, és nincs ennyi barátja a megkérdezettek 57\%-nak István-aknán. Magyarteleken ezzel szemben az emberek 2/3-a rendelkezik megfelelő számú baráttal, és csupán 1/3 nem.

A mikrotársadalomra korlátozódó kapcsolthálók nagysága főként körvonalazza, és kevésbé magyarázza a szolidaritást és a beágyazottságot, hiszen ezek az adatok a kapcsolattartás gyakoriságát, az interakciók minôségét és közvetlen vagy közvetett információs csatornáit nem jelzik. E tekintetben azt mondhatjuk, hogy a rokoni kapcsolatok alapján az István-aknai mikrotársadalom megkötő társadalmi tôkéje egy közepestôl elmaradó szintet mutat, mivel a népesség közel felének egy rokona sem él itt, és ugyanekkora hányadánál hiányoznak a szoros baráti kapcsolatok, sốt kiemelkedôen magas azok aránya, akik csak egy baráttal vagy eggyel sem rendelkeznek. Magyartelek esetében viszont ezek az értékek rendre jóval alacsonyabbak, és az integráltság magasabb fokát jelző értékek vannak többségben

A szolidaritást már magasabb szinten képes magyarázni a puszta kapcsolatszám helyett a megkötố társadalmi tốke következố csoportja, a közvetlen szomszédokkal személyesen, legalább havonta egyszeri alkalommal tartott interakciók száma, hiszen itt a kapcsolatok mennyisége mellett már adottak a minőségi változók is.

A szomszédi viszony már nem feltétlen baráti, vagy vérségi rokoni kapcsolatokat jelent. Vagyis minél magasabb ezen kapcsolatok száma, annál inkább lehet beágyazódott az individuum az István-aknai városrész mikrotársadalmába. István-aknán az emberek fele 3-nál kevesebb ilyen kapcsolattal rendelkezik, és 22\%-nak van 4 és 6 közötti (tételezzük fel) már „jó szomszédsági” viszonya. Ez egy igen magas arány, és alátámasztani látszik azt az adatfelvétel során kialakult tapasztalatot, miszerint István-akna területi sajátosságai, csekély népessége és annak homogenitása ellenére szerkezetileg belsôleg is több részre tagolódik. Ezeket a szerkezeti egységeket nagyjából a lakóépületek jellege körvonalazza, amelyek a 2 szintes (egykori bányász mun- kásszállók) téglaépuletek (3db épületenként 16 lakás) lakásai, az igenyesebb kivitelú bányatiszti kertes családi házak, illetve a kisebb igényességgel kialakított, de még mindig az átlagon felüli bányászházak. A szomszédi kapcsolatok túlnyomórészt alacsony száma (1-3), arra enged következtetni továbbá, hogy a kutatás során kialakult szerkezeti tagoltságról alkotott elképzelést még kisebb csoportokra, a közvetlenü egymás mellett éló szomszédokra kell redukálni. Mivel azonban arra vonatkozóan, hogy ezeket a szomszédokat kik jelentik (a településrész mely részén lakók) nincs adatunk, empirikusan ezt a tézist nem tudjuk alátámasztani.

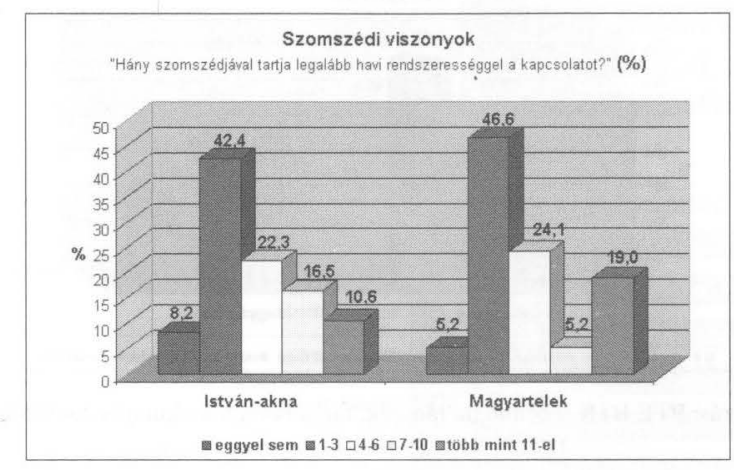

Forrás: PTE BTK szociológia tanszék, társadalmi tốke kutatás 2005/2006

Az eddigi mutatókat figyelembe véve meglepő eredményeket kapunk Magyartelek esetében, hiszen István-aknához hasonlóan rossz képet (ha nem rosszabbat) mutat a szomszédi viszonyoknál. Ez annál is inkább meglepó, mivel nagyon sokan beszéltek a falubeliek összességéról úgy mint rokon. Vélhetôen a „szomszéd” fogalmának konceptualizációja, és a válaszadók hozzá rendelt jelentése közötti különbség okozhatja a problémát, hiszen ha szomszédon mindenki csak a közvetlen mellette lakó embereket érti, ez leszúkíti a válaszok körét. Mivel mindkét esetben a területi kiterjedés és az alacsony népességszám az erôs és kiterjedt szomszédi kapcsolatokat támasztaná alá, az adatok gyengítik a megkötő társadalmi tóke eddigi eredményeit.

\section{Bizalom általában}

z általában az emberek felé táplált bizalom kérdésé nem közvetlenül kapcsolóAdik a mikrotársadalmak szolidaritásához, mivel nem az egyes emberek irányába mutató bizalmat jelzi, hanem egyfajta attitûdöt, hozzáállást. Minden bizonnyal az egyik legjelentôsebb mutató lenne, ha mindenki egy-egy megnevezett személyt minősített volna iránta érzett bizalmával, ám ezek a kutatások nem kapcsolati hálók elemzésére születtek. Azonban az általános bizalomról való gondolkodás befolyásolja és jelzi a lakóhely tagjai közötti formális kapcsolatok viszonyait, ezek mellett az Utasi Agnes által végzett vizsgálat is alkalmazza ezt a kérdést. Ezeknek megfelelốen bár fontos mutatónak tartom, nem a legjelentôsebb magyarázó változó a vizsgálatban. István-akna esetében rendkívül magas azok aránya, akik szerint nem lehet megbízni 
senkiben, és mindössze 5\% mondta azt, hogy a legtöbb ember megbízható, míg Ma-

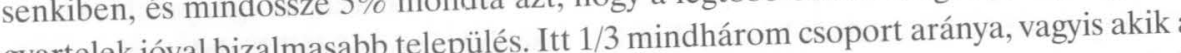

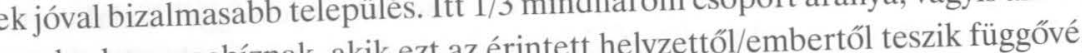
legtöbb emberben megbiznak, akik ezt az érintett helyzettólembertótével ezek és akik senkiben sem bíznak. A kérdés jelentőségének figyelembe vételévelezek adatok a helyiek formális kapcsolatait István-aknán bizalmatlannak, Magyarteleken közepesen bizalmasnak mutatják.

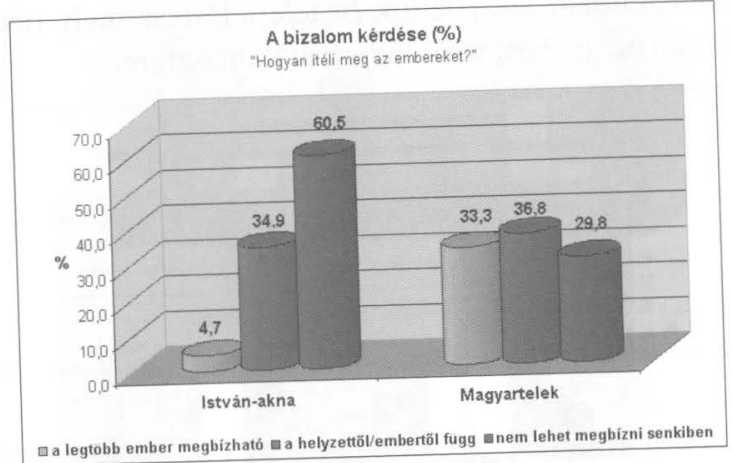

Forrás: PTE BTK szociológia tanszék, társadalmi tốke kutatás 2005/2006

\section{Háztartások közötti transzferek}

mikrotársadalmi szolidaritás egyik legfontosabb mutatóit az egyének közöt A mikrotársadán ellenszolgáltatásra igényt nem formáló segítố szándék létét és minőségét, illetve gyakorlati eredményeit a nem formáló segén. mikrotársadalmi szolidaritás szintjêt leginkä́n típusokra bontottuk annak megfelelően, A nyújtott és kapott segítségeket kulonbözo tipusokra bontottuk án hogy mire lehet szüksége egy deprivált térségben éló, esetleg hátrányokkal küzdố em-

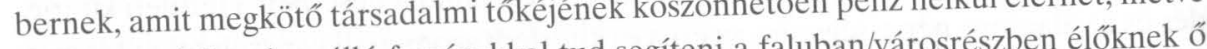
milyen rendelkezésre álló forrásokkal tud segíteni a faluban/vârosrészben élóknek o maga. Átlagokat nézve a népesség 78,5\%-a soha nem ad, és $64,52 \%$ soha nem kap semmifajta segítséget elmondása szerint István-aknán, és közel hasonlóan alakulnak mutatók Magyarteleken is. A juttatott támogatási formák megközelítőleg kiegyenaźn részesülés tekintetében, ami azzal magyarázható, hooy a lekérdezés mind István-akna mind Magyartelek egészére kiterjedt. f́co is belekerült az adatbázisba, akiktől a forrás származott, és azok is, akikhez vélhetóen eljutott.

A transzferek különböző típusaira való lebontásával kapott eredményeket rangsolva választ kaphatunk arra, hogy mire van a legnagyobb szükség, és hogy milyen 等 az adott helyen. Ezek fényében kiemelkedô mind István-aknán mind Magyarteleken rendszeresen vagy alkalmilag nyújtott pénzbeli támogatás ami bár meglepó, hiszen a rendszer én legkésarra számíthatnánk, hogy a leszakadó térségekben éredményeivel.
Transzferek
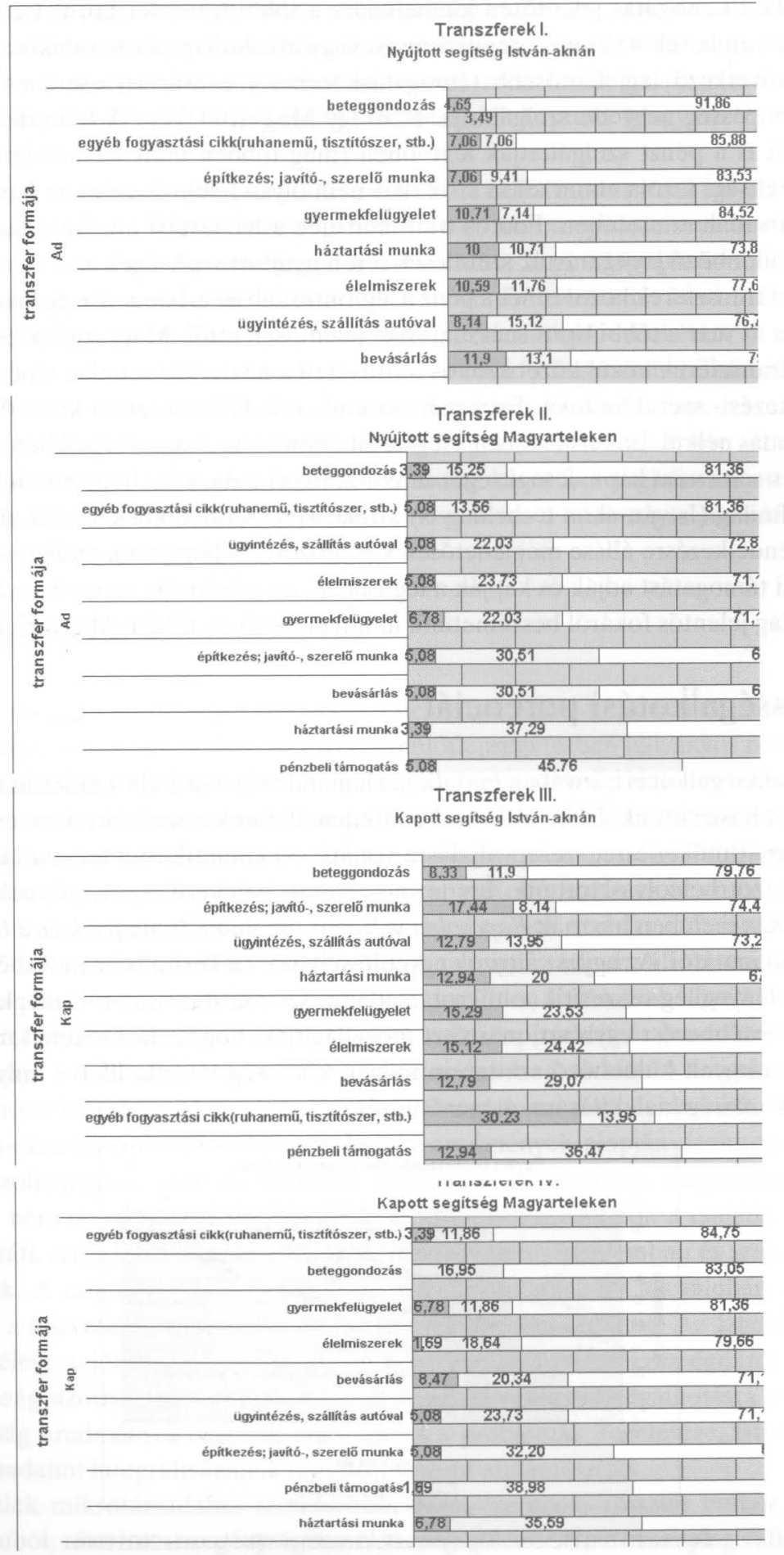
A pénzbeli támogatás jelentôsen kiemelkedik a többi transzfer közül István-aknán hiszen az emberek $45 \%$-a ad rendszeresen vagy alkalmilag pénzt valakinek, míg az utána következő legjelentősebb támogatási forma (bevásárlás) esetében ezt már csak a népesség negyede szolgáltatja. Nem így Magyarteleken. A transzferek közül ugyan itt is a pénzt szolgáltatják legtöbben (még többen mint István-aknán), de a többi segítségi forma elmaradása ettôl már nem olyan jelentős, mint az István-aknai mikrotársadalom esetében. Fontos transzfer még a háztartási munka, a bevásárlás, vagy a különböző javítgatások, szerelések terén nyújtott segítségek is.

A kapott transzferek közül ismét a pénz a legfontosabb az urbánus térség lakói között, azonban itt már a többi típus sem marad el jelentôsen ettốl. Magyartelek esetében a kapott transzferek közül közel azonos fontosságú a háztartási munka, a pénz, illetve az építkezési- szerelőmunka. Ezeket itt az emberek $40 \%$ élvezheti közvetlen ellenszolgáltatás nélkül. Bár első látásra a legszembetűnőbb az, hogy a legtöbben soha nem adnak és soha nem kapnak segítséget senkitôl, figyelembe véve hogy mindkét terület társadalmilag (István-akna térbelileg is) kirekesztett területeknek számít ahol a források rendelkezésre állása meglehetôsen korlátozott, és hogy ezek mellett az anyagi, pénzbeli támogatást adják és kapják a legtöbben, a szolidaritás nem elhanyagolható, viszonylag jelentős fokáról beszélhetünk mindkét esetben, főként Magyarteleken.

\section{Közösségalkotási potenciál}

közösségalkotás irányában mutatkozó hajlandóság méréséhez indexált mérốszáAmot használtunk. Ebbe az indexbe minden általunk a szolidaritásra, és a társadalmi együttmúködésre, szerepvállalásra vonatkozó autentikusan felhasználhatónak vélt változót beleolvasztottunk. Így természetesen belekerültek a mikrotársadalmi szolidaritás esetében használt Kapcsolati változók, az Adott Transzferek és a Lakóhelyi integráció mutatói. Az egyes változók egyenlô súlyozással kerültek az indexbe.Ezek az indexek lényegileg összesítik a mikrotársadalmi szolidaritás mutatóit megkönnyítve ezzel az értelmezést egyrészt, másrészt megvilágítják, hogy a társadalmi kirekesztődés fent tárgyalt különböző színterein milyen közösség létezik, illetve milyen esély adott a közösség kialakítására, megerôsítésére.

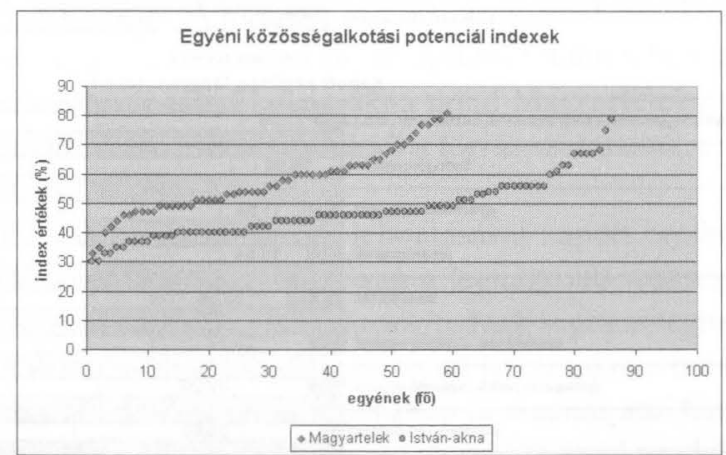

Forrás: PTE BTK szociológia tanszék, társadalmi tốke kutatás 2005/2006
Nyilvánvaló, az eddigiek alapján szinte előre látható különbség van a rurális- és az urbánus deprivált terület között. Az index értékek lényegi többsége $50 \%$ feletti Magyartelek esetében, ahol az értékek növekedése is jóval intenzívebb. Ez azt jelenti, hogy a fentieket átlagolva 57\%-os közösségalkotási potenciált kaptunk Magyarteleken.

István-aknán az indexek több mint 2/3-a nem éri el az 50\%-ot és jóval lassabban növekednek az értékek. Vagyis összességében 47\%-os közösségalkotási potenciált kapunk a városi területen. Ez arra enged következtetni, hogy Magyartelek adottságai sokkal jobbak egy közösség életben tartására, megerôsítésére mint István-aknán. Itt ugyanis elôszzör annak létrehozásával kell foglalkozni, aminek érdekében az adatfelvétel óta eltelt idő alatt elôrelépések születtek az ott folyó városrehabilitáció keretei között (több-kevesebb sikerrel), de erre most nem térek ki. Véleményem szerint ezt a különbséget nyilván nem a demográfiai különbségek (hiszen azok szinte azonosak), hanem a falu és a város társadalmának identitása közötti, a foglalkoztatottságban mutatkozó eltérések, a vezető szerepe, és természetesen a közösségi színtér létezése/ hiánya magyarázhatja leginkább.

\section{Következtetések}

fenti vizsgálat eredményei egybecsengenek Utasi Ágnes kutatásaival. A társadalAmi kirekesztettségben élő́k, az esélyegyenlốtlenségi térben hátrányos pozíciókat betöltốk társadalmi integrációja életlehetőségeik korlátozottságának mértékével párhuzamos. Minél több társadalmi hátrány között él valaki, annál kisebb bizalmas kapcsolatainak köre, annál kevésbé mutat altruista magatartást, annál kevésbé szolidáris, és annál kevésbé integrált a társadalomba. A kapaszkodót ezeknek az embereknek a család és néhány közeli barát jelenti, melyek kiszakadásuk utolsó védóbástyái. A társadalmi tốkével szúkölködők saját helyzetükön nemigen tudnak változtatni, hiszen a társadalmi tóke hiánya az életkörülmények kedvezôtlen hatásainak következménye. A kialakult helyzet behatárolja ezen emberek tudati aspirációit, és gondolkodásmódját, kialakítja a boldogtalanságérzést, vagy a deviáns magatartást. A folyamat szinte öngerjesztố módon húzza kijjebb és kijjebb, a társadalom szélére az egyént.

Az István-aknaiak mikrotársadalma a kapott eredmények alapján dezintegráltnak, kevéssé szolidárisnak, individualizáltnak mondható. A szolidáris magatartások minôségileg nem de mennyiségileg gyengék, a bizalmas kapcsolatok a családi, rokoni, közeli baráti, szomszédi kapcsolathálók ugyancsak alacsony számban és színvonalon múködnek. A mintegy 300 fốs városrészben és a mintegy 300 fôs faluban a lakók többsége a közvetlen szomszédjaival tartja csupán a kapcsolatot. Az István-aknaiak megítélése saját szolidaritásukról, önzetlenségükről, segítókészségükről kedvezổtlen, beágyazottságuk alacsony szintjét mutatja. A közösségalkotásra irányuló hajlandóság eredményei hagynak némi esélyt a problémák kezelésére, István-akna mikrotársadalmi integráltságának mutatóit viszont alátámasztják.

Magyartelek mikrotársadalmi szolidaritása ezzel szemben, résszint eszköz jellegú adottságaiból, résszint a szegénységben élés megszokásából, a viszonylag változatlan 
népességéből, vagy a némileg kevesebb hátránnyal küzdố helyzetbốl kifolyólag adódik. A szegénység, mely az Ormánságban nem mostanában újonnan jelentkezô, hanem évszázados múltra visszatekintố probléma amint arról már a népi szociográfák is szólnak a 30'-as években, ennek megfelelỏen nem feltétlen determináló tényezó a mikrotársadalmi integráció és a társadalmi tóke mértékénél, legalábbis rurálisdeprivált viszonylatban nem. A két leszakadó térség társadalmi tóke szempontú öszszevetése a falu közösségi értékeit, mint hasznosítható forrásokat kiemelkedóbbnek mutatja István-aknával szemben, ahol ezen értékek kialakítását célzó beavatkozásokat lenne szükséges sürgetni.

\section{Felhasznált irodalom}

Coleman, James (1998): A társadalmi tốke az emberi tốke termelésében, In Lengyel György-Szántó Zoltán (szerk.): Tókefajták: A társadalmi és kulturális erổforrások szociológiája. Budapest: Aula udapest: Osiris, 85-141.

Huszár Zoltán(2003): Emléklapok a pécsi bányászat történetébő̉. Pécs: Pécsi Bányásztörténeti Alapítvány Tönnies, Ferdinand(1983): Közösség és társadalom. Budapest: Gondo:

Weber, Max(1987): Gazdaság és Társadalom. Budapest: Közgazdasági és Jogi Könyvkiadó

\section{Jegyzetek}

A népszámlálási adatokból Pécsre vonatkozó, városrészre lebontott adatok sem tartalmaznak külön Istvánaknára vonatkozó információkat.

2 Utasi (2002)

Forrás: Társadalmi-tốke kutatás, István-akna, PTE BTK Szociológia tanszék, 2005

4 Az épületek többségét a Duna Gởzhajózási Társaság építtette, a 19. században és a 20. század elején

\section{FEHÉr SzILVIA}

\section{Társadalmi tőke és egészségi állapot Pécsbányatelepen}

olgozatom célja a 2005 tavaszán rendezett társadalomkutatási gyakorlat részeként, Pécsbányatelepen készült kérdőíves egészségszociológiai vizsgálat eredményeinek bemutatása, a címben is szereplố társadalmi tôke és az egészségi állapot szempontjából. Mindezek megalapozásához először a kutatás elméleti hátterét nyújtom. Fényt derítek arra, hogy miként kapcsolódik egymáshoz a két fogalom, majd azok definíciójára, mérési lehetôségeire térek ki. A kutatás hipotézisének tárgyalása után a társadalmi tőke Pécsbányatelepen történt vizsgálatának eredményeit adom egy speciális tünetegyüttes, a depresszió szempontjából. Természetesen a betegség leírását is megteszem, a téma fontosságát alátámasztó, adatok közlését követően.

\section{A társadalmi tôke és az egészségi állapot Pécsbányatelepen}

z alapvetően felderítő jellegủ kutatás során a hipotézis, hogy a rossz anyagi hely- zet, gyenge infrastruktúra, kevés munkalehetőség, rossz életkörülmények miatt az emberek egészségi állapota nem megfelelố. Emellett homogén társadalmi környezet jellemzố, a kapcsolati tôke kiterjedt. Pécsbánya-telep Pécs keleti városrészéhez tarozik, viszonylag szegregált terület. Korábban a múködố kitermelés szervezte a közösségi életet, és adta a megélhetési lehetôséget. Azonban a bánya bezárásával ez megszű́nt, szerepét semmilyen szervezố erố nem vette át. Ezzel együtt az itt élố lakosság elvesztette munkahelyét, elszegényedett, és megkezdổött a roma lakosság beáramlása. A kutatás során célunk a speciális dimenziókra való összpontosítás volt az egészségszociológia vizsgálati tárgyain belül, melyek a társadalmi tőkéhez szorosan kapcsolódnak. Ezek az egészségügyi egyenlőtlenségek, lelki és fizikai egyenlőtlenségek, az egészségi állapot kiemelt tényezôi.

A kutatás módszerei között az interjú és kérdőíves megkérdezés egyaránt szerepelt. A helyi intézmények esetében (helyi képviselő, iskolaigazgató, lelkész, védốnô, háziorvos, családgondozó) strukturált interjú alkalmazása történt, amelynek során lehetôvé vált, hogy pontos képet kapjunk a helyi viszonyokról a témában legtöbb információval bíró szakemberektől. A lakosság körében kérdőíves megkérdezés alkalmazása folyt, melynek segítségével a helyi emberek szemszögéból is értesülhettünk Pécsbányatelepen uralkodó állapotokról. A munka végeredményeképp 77 kitöltött kérdőív született. Ez a kis elemszám módszertani korlátokat vet fel, hiszen az elemzésból született eredmények csupán jelzésértékúek lehetnek, ám további kutatási hi- 